AIAA-2002-3334

\title{
Recession Curve Generation for Space Shuttle Solid Rocket Booster Thermal Protection System Coatings
}

\author{
Howard S. Kanner \\ C. Irvin Stuckey ${ }^{\dagger}$ \\ Uniled Space Alliance, LLC. Cape Canaveral, FI. 32920 \\ Darrcll W. Davis" \\ NASA Marshall Space Flight Center, Huntsville. AL 35812
}

Ablatable Thermal Proloction System (TPS) coulings are used on the Space Shutle Vehicle Solid Rocket Boosiars in order to protecl the aluminum structure from experiencing excessive lemperalures. The methodology us $x$ to characterize the recession of such materials is outlined. Deluils of the tests. including the facility, lest articles and test article processing are also presented. The recession rales are collapscd into an empirical power-law rclation. A design curve is defined using a 95-percentile student-t distribution. based on the nominal tesults. Acrual test results are presented for the current acreage TPS material used.

\subsection{INTRODUCTION}

The following document summarizes the methodology used to determine the design recession ralc curves for the United Space Alliance Solid Rocket Booster element (USASRB) Thernal Analysis and Test Programs. Herein, we shall also include information about the test facilities typically used and the basic procedures followed, as well as somc typical data.

\subsection{RECESSTON DATA REDUCMTON METHODOLOGX}

When data is acquired during material characterization testing for the Space Shutuc Vehicle (SSV) Solid Rocket Boosters (SRBBs), it is processed to provide empirical relations to envelope the wurst recession rates expected to be experienced by the SRBs during flight.

Recession test data is acquired during material characterication thermal testing at George C. Marshall Space Flight Center (MSFC) Improved Hot Gas Fucility (IHGF, building 4554, Figure 1). Typical material characterization data sets include pro-test and post-test/post-scrape test pancl thickness measurcments, cold-wall heat rates and test duration. All the data is acquired at each of the 20 Jocations on the Medtherm calibration plate (Figure 4, H2501-H2520). Thickness measurements are acquired using a decp-throat micrometer. Cold-wall heat rates are compulcd from the measured hot-wall heal races acquired during calibration runs at Marshall Space lalight Center (MSFC) Improved Hot Gas Facility (1HGF) using the USA/THGF data reduction program, REDUCT. The correlation between cold-wall and hor-wall heat rates is defined in the following relation:

$$
\dot{q}_{w w}=\dot{q}_{n w} \times\left[\left(T_{r}-T_{o w}\right) /\left(r_{r}-T_{w}\right)\right]
$$

where:

$$
\begin{aligned}
& \dot{q}_{c w}=\text { cold wall heat rate, [BTU/ft'-sec, BFS] } \\
& \dot{q}_{\text {in }}=\text { hol wall heating rake, [BIU } / \mathrm{li}^{2}-\mathrm{sec} \text { ] } \\
& \because . \quad=\text { (adiabatic } w a l l) \text { recovery temperaturc } \\
& =r^{*} \times T_{\text {trisu }}\left[{ }^{\circ} \mathrm{F}\right] \\
& T_{\omega \mathrm{w}}=\text { cold wall reference temperalure }=0^{\circ} \mathrm{F} \\
& r_{*}=\text { surface temperaturc of calibration plate, }\left[{ }^{\circ} \mathrm{F}\right] \\
& r^{*}=\text { corrected recovery factor (for } M=4, y=1.4 \\
& \text { gas). [ND], typically } 0.92 \\
& =r+\frac{(1-r)}{1+\frac{r-1}{2} M_{r}^{2}} \text { and } r=0.89
\end{aligned}
$$

Recession rates are defined as the change in the thickness measurcment divided by the run duration. The run duration is delined as the time the total temperature measured in the combustor was stable.

\footnotetext{
- Analyrical and Test Engineer. SRB Luads \& Acrothennal Analysis Group. Seniur Meinber AlAA.

${ }^{\dagger}$ Anuly lical and Tese Engineer. SRB Loods \& Atrothermal Analysis Group.

Aerospice Enginour. Therınodynamics \& Heat Transfer Group.
} These materials are sponsored by the Naional Acronautics und Space Administration under Contrace NASO-20000. Tbe U.S. Govemment retains a paid-up. nonexclusive, irrevocable worldwide license in such mancrials in repruduce, prepare derivalive works. distribure copies to the public, and perform publicly and display publicly. by ur un behalf of the U.S. Govemment. All uther rights are reserved by the copyright owner. 
Typically, data from calibration pancl locations 7 and 8 (H2507, H2508) are neglected becausc the flow on the test panel is not fully established at those locations. Point 14 (H2514) may also be ignorod. depending on test conditions such as shock encroachment, etc...

\subsection{Methodology}

The rccossion data is ploued on a log-log plane. A linear least-squares curve fit to the log of the raw data values results in a recession ratc cquation of the following power-law form:

whore:

$$
\dot{r}=k \dot{q}_{i w}
$$

$$
\begin{aligned}
& \dot{r}=\text { recession rate [mils/sec] } \\
& \dot{q}_{\text {ow }}=\text { cold wall heating rate }\left(T_{*}=460^{\circ} \mathrm{R}\right) \text {, } \\
& \text { [BTU/fr'sec] } \\
& k=\text { empirical scale factor; lcast-squares fit } y \text { - } \\
& \text { intercept } \\
& x=\text { cmpirical exponcni; le ast-squares lit slope }
\end{aligned}
$$

This equation is, of course, linear in log-log space. When the thickness of the TPS required to protect the SRB hardware during flight is calcululed. a more conservative recession equation is used, known as the design equation. The former equation is known as the nominal equation. The design equation is based on a calculation of the 95\% Upper Prediction limil lor each ordered pair of recession rate as a function of cold-wall heating raic. The upper prediction limil is calculared using the following equation:

$$
Y=y+t_{\alpha / 2} \times S_{c} \times\left(1+1 / n+\left(x_{u}-\bar{x}\right)^{2} / S_{x x}\right)^{/ / 2}
$$

wherc:

$$
\begin{aligned}
y= & \text { cstimated valuc of dependent variable } \\
& \text { based on least-squares fit } \\
t_{u / 2}= & \text { constant for t-dismibution based on degrees } \\
& \text { of frcedom } \\
& \text { (df=number of data points-2) and the width } \\
& \text { of the prediction inrerval }(95 \%) \\
S_{e}= & \text { SQRT ((Slope of Standard Error)/df) } \\
x_{n}= & \text { independent variable } \\
\bar{x}= & \text { average value of independenl variable } \\
S_{x, 1}= & \sum\left(x_{i}-\bar{x}\right)^{2}
\end{aligned}
$$

This calculation results in a new set of recession rate values for the cold-wall heating rate distribution. A lincar, least-squares curve is fit to this adjusted data and the result is the design curve
If the data is not best fit with a single linear fit, it is subdivided into two or more heat-rate regimes for which the recession is lincer in character.

\subsection{Implementation}

The above methodnlogy is implemented in Micrusolt Execl spreadsheets. Curve lilling is complered using the LINEST() function. The student-l distribution extrapolation is completed using the TINV() function.

\subsection{Thiermal Testing}

As stated previously, material charactcrization testing is completed al NASA MSFC IHGF, shown in Figure 1. All material characterization testing is completed using constant heat rates of 5 to 15 BFS convectively. with a nominal recovery enthalpy of $600 \mathrm{BTU} / \mathrm{lb} \mathrm{b}_{n}$. Higher heat rates are achicved using a radiant are lamp, which can be using simultaneously with convective heating.

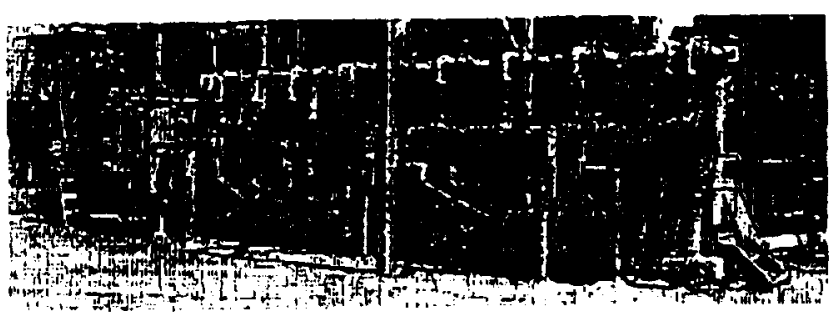

Figurc 1: Photograph of IHGF

\subsection{Improved Hot Gas Facility}

The IHGF is a nominal Mach 4.1 acrothermal tunnel that burns a lean mixture of hydrogen ( $\mathrm{GH}_{\text {}}$ ) and air to produce tcmperanures up to $2200^{\circ} \mathrm{F}$ at total pressures up to 200 psia. The tunnel has a nominal $16 \times 16 \times 40$-inch test section that was primarily designed lor the testing of thernal protection materials. However, provisions were made for a supporn strul and sting so that other aerothermal testing could be sccomplished in the facility. In the original design conliguration. each of the four walls of the lest section could accommodate a blank panel, a vicwing panel, or a test pancl. However, a model injection system has been added in the bottom wall opening that allows the test panel to be retracted during cunnel start and then injectod inro the flow at inclination angles from 0 to 15 dcgrees. The heating rates available in the IHGF with the model injection system arc shown in Figure 2. A picture of the test section is shown in ligure 3. A complete description of the tunnel is given by Palko ${ }^{2.3}$. A database with variables of combustor pressurc, combustor temperature, and injection angle from the injection system checkout calibration is availab]c at the facility to 
aid in selecting the tunnel oontrol settings for a desired test condition. However, calibration runs are normally made for cach lcst soquence to fine-tune the control settings for the spccilic lost conditions.

Radiant heating is also available by an arc lamp that can be fitted to the test section upper window. With a sctup of mirrors, the radiant heat is applied consistently over a portion of the test panc:, as indicated by the shaded zone in Figure 4.

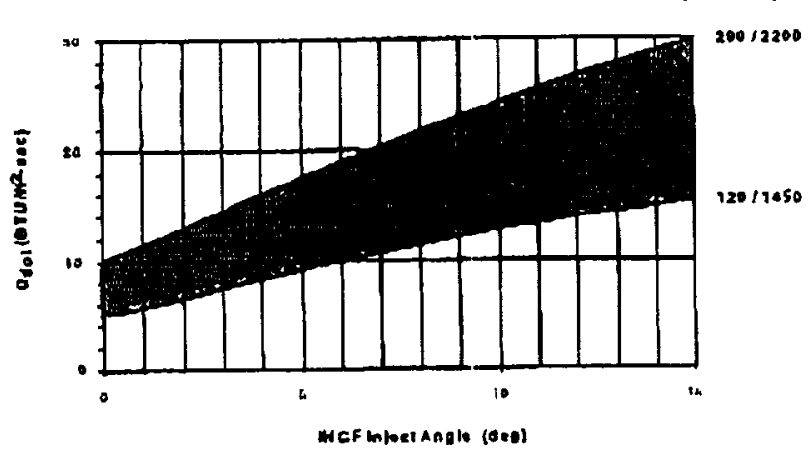

Figure 2: Obtainable Heat rare as a Function of Model Wedge Angle in the IHGF

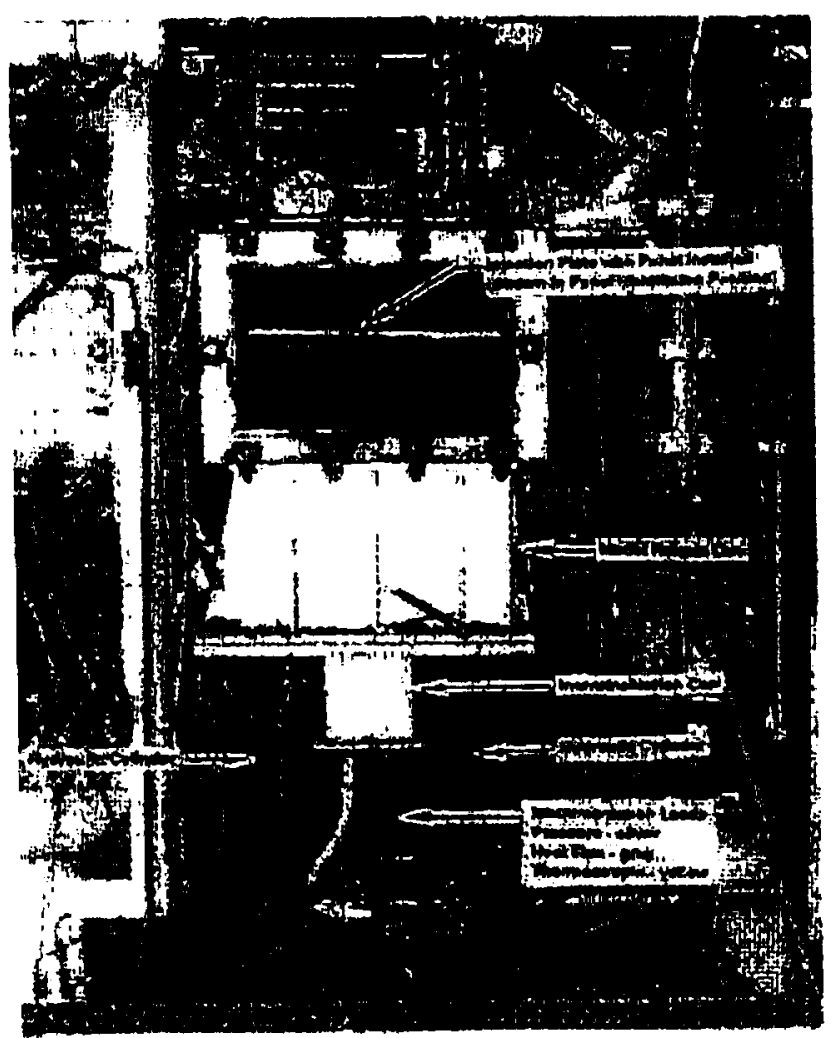

Figure 3: Photograph of IHCF Test Section and Model Injection Syitem

\subsubsection{Calibration Test Panel}

Test panels do not typically include calorimeters or any other means to measure incident heat flux on the surface. To delcmine the heat rates on test panels, a calibration nun is completed at cach test condition. The calibration test panel has a planform of $12 \times 19$-inches and includes 20 Medtherm Schmidt-Boelter typc transduccrs localed as indicated on Figure 4.

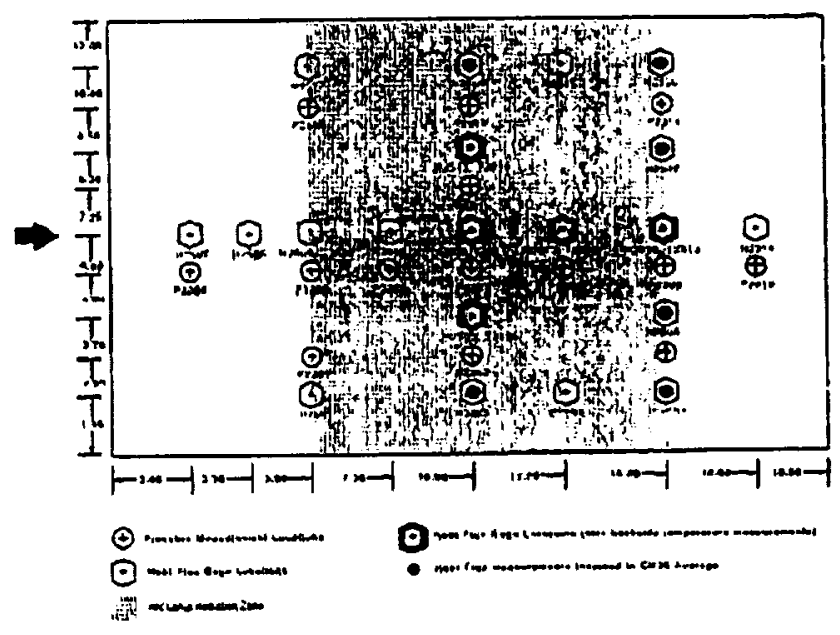

Figurc 4: Standard Convective Heating Medtherm Calibration Plate denoted with Radiant Footprint

A separatc calibration plate is available for radiant-only testing, which includes radiometers as well as calorimeters.

\subsubsection{Test Panels}

The test panels, like the calibration panels, have a $12 \times 19$-inch planform. Typically, they are $1 / 4$-inch thick aluminum. TPS is applied on the surface with typical thickness up to $1 / 2$-inch. Using a lcmplate that inatches the locitions of the calorimeters on the Medthem calibration plate, thickncss measurements are made, both before and after testing using a doep throat micrometer (0.001-inch graduations). Pre- and post-test papel photographs are in Figure 5 and Figure 6. 


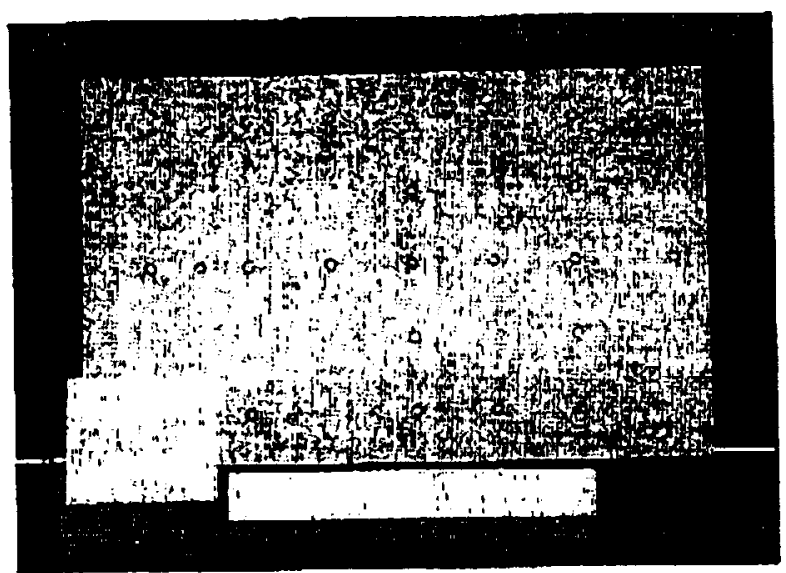

Figure 5: MCC-l Test Panel Pro-Test Photograph

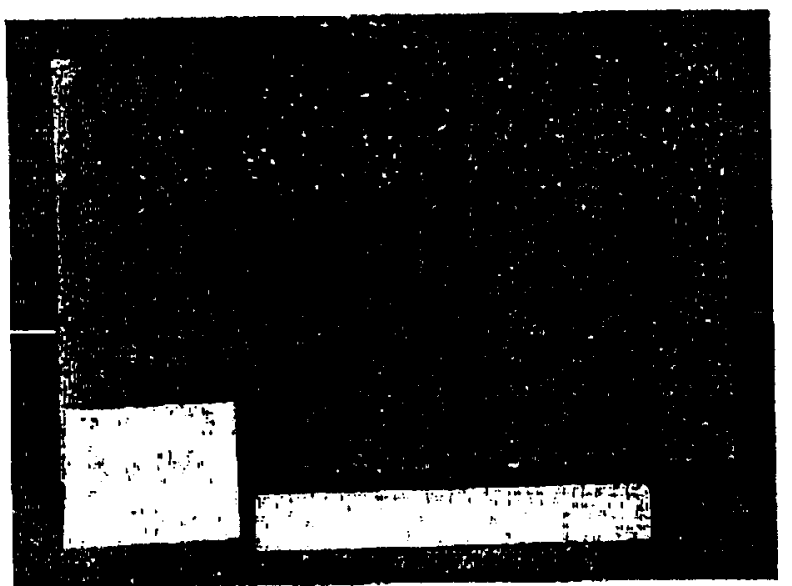

Figure 6: MCC-1 Test Pancl Post-Test Photograph

After texling, the test pancls consist of virgin material covered with ablation by-products, defined as a "heataffected" layer and a char layer. Recession, for USASRB, is derined as the loss of virgin material, thus the char and heat-affected layirs need to be removed for final measurcments. These layers are removed by scraping the test pancls. Depending on the TPS, hand scraping ar mechanical scraping are done. Hand scraping is achieved using paint scrapcrs, while mechanical scraping is competcd using coarse or fine Roto-Suripper ${ }^{\mathrm{M}}$ tools in an electric drill (Figure 7).

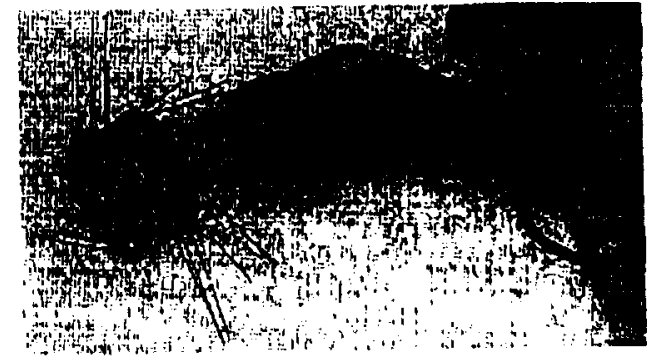

Figure 7: Roin-Surippor 'lool for Removing Char Layer

\subsection{Actual Test Data}

Within this scction, we present lypical test data and the resulting recession characterization curves; both nominal and design. The data presented is for an acreage TPS, MCC-1 on the SRB nose cap, frustum, forward skirt and aft skirt. The data is presented in both linear space (Figurc 8) and logarithmic space (Figure 9). Both tormals are presented to graphically illustrate the non-linear trend of the data set.

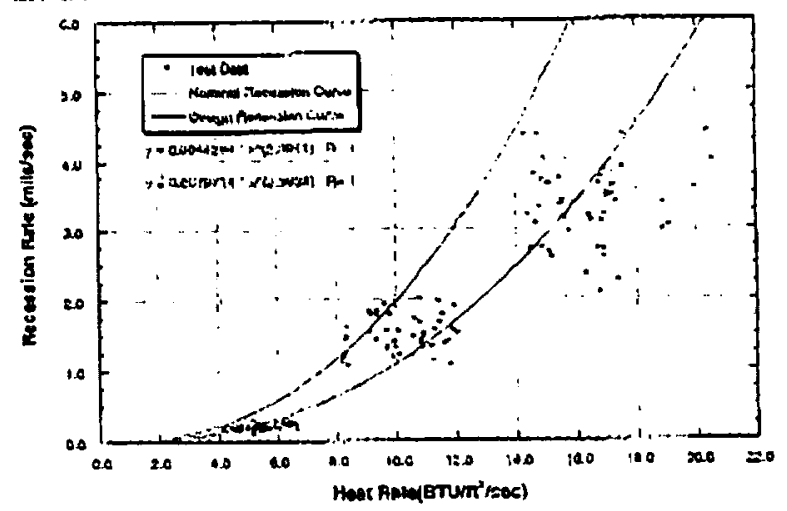

Figure S: MCC-1 Recession Data in T.inear Space

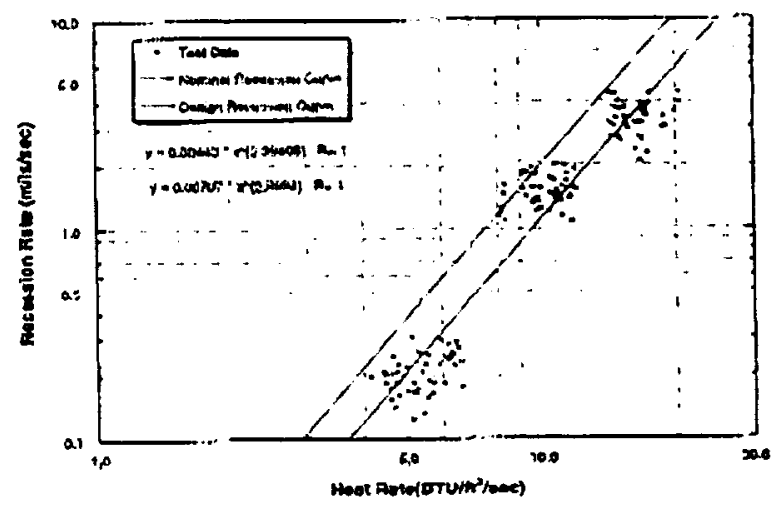

Figure 9: MCC-1 Recession Data in L-ogarithmic Space 


\subsection{SUMMARY AND CoNCLUSIONS}

Material characterization for TPS materials used on the Space Shuttle Vchicle Solid Rockct Boosters are performed at NASAMSFC IHGF. Constant heat rates are applied to flat panels for lixed durations. The known rest duration and the resultant measured rocession is then used. with a power-law relationship and a student- $t$ distribution, to define the nominal and design recession rares, where the design rates are such that $95 \%$ of all sample recession is represented.

It should be noted that all recession characterization completed by USASRB/Thermal Tcsting and Analysis is at a lixed recovery enthalpy of $600 \mathrm{BTU} / \mathrm{bm}$, which is the maximum value to which the SRBs are subject. It is considered conservative to tcst at this upper limit for this program. Accounting for variations in the recovery enthalpy would be roquired to use the data below for other applications.

\subsection{ACKNOWLEDGPMENTS}

The authors would like to express appreciation to the Uniled Space Alliance and NASA Marshall Space Flight Cenlet SRB Project Office for their cooperation and support.

\section{References}

1 Ott, Lyman, An Insroduction w' Statistical Methodx and Data Analysis, PWS-KENT Publishing Company, Boston, MA, 1988.

2 Palko, R. L.. "Technical Design of the NASAMSFC IHGF," REMTECH Repon RTR 17003, February 1988.

${ }^{3}$ Palko, R. L. 'NASAMSPC IHGF Calibration Report. Volume 1 - Perfarmance and Operation", REMTECH Report RTR-210-01, August 1989. 